\title{
SYMMETRIC-ELECTROMYOGRAPHIC ANALYSIS IN THE EVALUATION OF SCOLIOSIS TREATMENT
}

\author{
ANÁLISE POR SIMETROGRAFIA E ELETROMIOGRAFIA NA AVALIAÇÃO DE TRATAMENTO DA ESCOLIOSE
}

ANÁLISIS POR SIMETROGRAFÍA Y ELECTROMIOGRAFÍA EN LA EVALUACIÓN DE TRATAMIENTO

DELAESCOLIOSIS

Wally auf der Strasse

(Physical Education Professional)

Karen Regina Galvão de Oliveira² (Statistician)

Lucas Menghin Beraldo

(Physical Education Professional)

Adriana Maria Wan Stadnik'

(Physical Education Professional)

1. Universidade Tecnológica Federal do Paraná, Biomedical Engineering Graduate Program, Health Management and Clinical Engineering Study Group, Curitiba, PR, Brazil.

2. Universidade Federal do Paraná, Curitiba, PR, Brazil.

\section{Correspondence:}

Adriana Maria Wan Stadnik Health Management and Clinical Engineering Study Group, Biomedical Engineering Graduate Program, Universidade Tecnológica Federal do Paraná. Rua Omílio Monteiro Soares, 1360, Curitiba, PR, Brazil. 81030-001. wallystrasse@hotmail.com

\begin{abstract}
Introduction: Scoliosis is a three-dimensional deformity of the spine, characterized by a lateral shift that affects body posture. The Pilates Method (PM) promotes alterations in the biomechanics and neuromuscular activation pattern. Objective: The aim of this study was to analyze electromyography (EMG) and symmetrography (SMTG) technologies applied in the evaluation of neuromuscular and postural effects on right convex thoracolumbar scoliosis (RCTS) after applying a PM therapeutic protocol. Methods: This is an exploratory study of 5 male and female adolescents, with an average age of 14.4 years. The subjects underwent postural asymmetry assessments through SMTG and neuromuscular assessment through surface EMG of the trapezius (TRAP), erector spinae (ERE), oblique (OBLI) and rectus abdominis (RA) muscles. The electromyographic signals were processed in the temporal ( $E M G_{A m p}$ ) and spectral ( $E M G_{\text {Fmed }}$ ) domains. The therapeutic protocol consisted of 24 sessions of Pilates floor exercises held twice a week with a duration of 45 minutes. Results: There was an improvement in scoliosis and asymmetric shoulders in one subject (20\%) and in three other subjects with hip asymmetry. There was

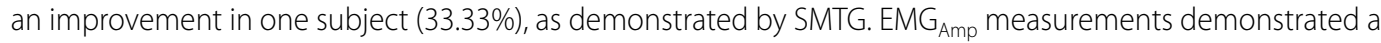
significant difference between before and after $(p \approx 0)$ and among the muscles $(p \approx 0)$. $E M G_{\text {Fmed }}$ measurements demonstrated that there was only a difference between before and after $(p \approx 0)$. It was verified that the most noteworthy muscles in terms of EMG ${ }_{A m p}$ were TRAP and ERE, emphasizing the existence of an increase in the mean $E M G_{A m p}$ for $E R E$. Muscle behavior for measurements in $E M G_{F m e d}$ demonstrated a higher mean increase for RA and OBLI muscles. Conclusion: It is concluded that the EMG and SMTG technologies are important tests for monitoring the progress of scoliosis and in treatment decisions. Level of Evidence III; Diagnostic Studies Investigating diagnostic tests.
\end{abstract}

Keywords: Pilates Training; Scoliosis; Electromyography; Posture.

\section{RESUMO}

Introdução: A escoliose é uma deformidade tridimensional da coluna vertebral, caracterizada por um desvio lateral que afeta a postura corporal. O método Pilates (MP) promove alterações na biomecânica e no padrão de ativação neuromuscular. Objetivo: O objetivo deste estudo foi analisar a eletromiografia (EMG) e a simetrografia (SMTG) aplicadas na avaliação dos efeitos neuromusculares e posturais sobre a escoliose toracolombar destro-convexa (ETLDC), após aplicação de um protocolo terapêutico do MP. Métodos: Trata-se de um estudo exploratório com cinco adolescentes de ambos os sexos, com média de idade de 14,4 anos. Os pesquisados foram submetidos a avaliações de assimetria postural por meio da SMTG e avaliação neuromuscular por meio da EMG de superfície dos músculos trapézio (TRAP), eretores da espinha (ERE), oblíquos (OBLI) e reto do abdome (RA). Os sinais eletromiográficos foram processados nos domínios temporal $\left(E M G_{\text {Amp }}\right.$ ) e espectral $\left(E M G_{\text {Fmed }}\right)$. O protocolo terapêutico foi constituído por 24 sessões do MP de solo, aplicado duas vezes por semana, com duração de 45 minutos. Resultados: Houve melhora da escoliose e dos ombros assimétricos em um indivíduo (20\%) e em três outros com assimetria de quadril; houve melhora em um individuo, (33,33\%), de acordo com a SMTG. As medidas da $E M G_{\text {Amp }}$ demonstraram diferença significativa entre antes e depois $(p \approx 0)$ e entre os músculos $(p \approx 0)$. As medidas da $E M G_{\text {Fmed }}$ demonstraram que houve diferença apenas entre antes e depois $(p \approx 0)$. Verificou-se que os músculos de maior destaque para $E M G_{\text {Amp }}$ foram TRAP e ERE, ressaltando que houve um aumento na média de $E M G_{A m p}$ para ERE. O comportamento da musculatura para as

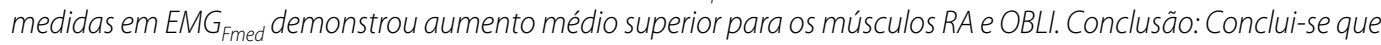
as tecnologias da EMG e a SMTG são importantes exames no acompanhamento do quadro evolutivo da escoliose e nas decisões de tratamento. Nível de Evidência III; Estudos Diagnósticos - Investigação de testes diagnósticos.

Descritores: Método Pilates; Escoliose; Eletromiografia; Postura.

\section{RESUMEN}

Introducción: La escoliosis es una deformidad tridimensional de la columna vertebral, caracterizada por un desvío lateral que afecta la postura corporal. El método Pilates (MP) promueve alteraciones en la biomecánica y en el patrón de activación neuromuscular. Objetivo: El objetivo de este estudio fue analizar la electromiografía (EMG) y la simetrografía (SMTG) aplicadas en la evaluación de los efectos neuromusculares y posturales sobre la escoliosis 
toracolumbar dextroconvexa (ETLDC) después de aplicación de un protocolo terapéutico del MP. Métodos: Se trata de un estudio exploratorio con cinco adolescentes de ambos sexos con edad promedio de 14,4 años. Los encuestados fueron sometidos a evaluaciones de asimetría postural por medio de la SMTG y evaluación neuromuscular por medio de la EMG de superficie de los músculos trapecio (TRAP), erectores espinales (ERE), oblicuos (OBLI) y recto abdominal $(R A)$. Las señales electromiográficas fueron procesadas en los dominios temporal ( $E M G_{A m p}$ ) y espectral ( $E M G_{\text {Fmed }}$. El protocolo terapéutico fue constituido por 24 sesiones de MP de suelo, aplicado dos veces por semana, con duración de 45 minutos. Resultados: Hubo mejora de la escoliosis y de los hombros asimétricos en un individuo (20\%) yen tres otros con asimetría de cadera; hubo mejora en un individuo, (33,33\%), de acuerdo con la SMTG. Las medidas de la $E M G_{\text {Amp }}$ demostraron diferencia significativa entre antes y después $(p \approx 0)$ y entre los músculos $(p \approx 0)$. Las medidas de la $E M G_{\text {Fmed }}$ demostraron que hubo diferencia sólo entre antes y después $(p \approx 0)$. Se verificó que los músculos de mayor destaque para EMG Amp $_{\text {fueron } T R A P \text { y ERE, resaltando que hubo un aumento en el promedio de EMG }}$ Amp para ERE. El comportamiento de la musculatura para las medidas en $E \mathrm{EG}_{\text {Fmed }}$ demostró un aumento promedio superior para los músculos RA y OBLI. Conclusión: Se concluye que las tecnologías de la EMG y la SMTG son importantes exámenes en el acompañamiento del cuadro evolutivo de la escoliosis y en las decisiones de tratamiento. Nivel de evidencia III, Estudios Diagnósticos - Investigación de Exámenes Diagnósticos.

Descriptores: Método Pilates; Escoliosis; Electromiografía; Postura.

\section{INTRODUCTION}

Scoliosis is one of the most common spinal disorders, and its diagnosis and late treatment can lead to complications in body posture ${ }^{1}$. The prevalence of scoliosis in Brazil ranges from 2\% to $4 \%$ in adolescents aged between 10 and 16 years ${ }^{2}$.

Most cases of scoliosis occur during the accelerated growth phase ${ }^{3}$ because of the uneven growth of the vertebrae or by the unbalanced development of the dorsal muscles ${ }^{4}$. The overload on capsules, ligaments, and intervertebral disks, which are responsible for the stability of the spine, promote muscle damage to structures and cause pain ${ }^{5}$.

Treatment protocols $s^{6,7,8}$ in accordance with the classification of scoliosis provide biomechanical changes to soft tissues, which lead to a reduction in the progression of the scoliotic curvature and promote the sagittal balance of the spine ${ }^{9,10}$.

The pilates method (PM) is based on the following six principles: breathing, control, concentration, centering, flow of movement, and precision. The muscle exercises in the PM are characterized by low contractional impact, with emphasis on strengthening the abdominal and paravertebral musculatures ${ }^{11}$. However, even with the beneficial effects provided by this technique, studies on this modality as a therapeutic alternative are scarce ${ }^{12}$.

Therefore, the objective of this study was to analyze posture using symmetrography (SMTG) and surface electromyography (EMG) technologies used in the evaluation of neuromuscular effects and postural application of a therapeutic protocol consisting of PM floor exercises in adolescents with a medical diagnosis of right convex thoracolumbar scoliosis (RCTS), including a case of RCTS presenting with a Cobb angle of $>40^{\circ}$, and an indication of corrective surgery.

\section{MATERIALS AND METHODS}

Five male and five female adolescents with a mean age of 14.4 years and medical diagnosis of RCTS were selected for the study. The study was approved by the Research Ethics Committee Involving Humans of the Federal Technological University of Paraná - UTFPR under No. CAEE: 36614014.0.0000.5547. The study was conducted over a period of 12 weeks, from February to April 2015. All the participants signed the Free and Informed Assent Term (FICT), and the legal representatives signed the Free and Informed Consent Term (TCLE).

The EMG System do Brasil ${ }^{\circledR}$ Model 1600-U12 electromyography equipment with 16 channels and $3 \mathrm{M} \mathrm{Ag/AgCl}$ surface electrodes were used for the evaluation of the electromyographic signals.
Postural asymmetries were analyzed with a Cardiomed WCS symmetrograph, in a flexible banner crystal measuring $180 \times 70 \mathrm{~cm}^{2}$, with $5-\times$ 5 -cm divisions aligned vertically to the plumb line and a base platform with drawings of footprints, measuring $40 \times 40 \mathrm{~cm}$.

Electromyographic signals were processed in the MATLAB ${ }^{\circledR}$ R2008a program (MathWorks, Inc) with third-order Butterworth type 30- to 450$\mathrm{Hz}$ bandwidth filtering and band reject-type filters over the harmonic of the electrical network $(60,120,180,240,300,360$, and $420 \mathrm{~Hz}) . \mathrm{EMG}_{\mathrm{Amp}}$

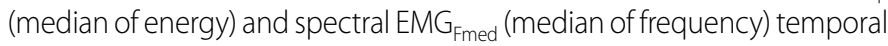
analyses were performed. The frequency median was processed with the fast Fourier transform according to equation (1),

$$
M F=\int_{0}^{M F} P(f) d f=\frac{1}{2} \int_{0}^{f S / 2} P(f) d f \quad(1)
$$

where MF is the median frequency, is the power spectrum, and fs is the sample frequency.

Time domain EMG signal processing was performed using the median absolute (or rectified) amplitude equation shown in equation (2),

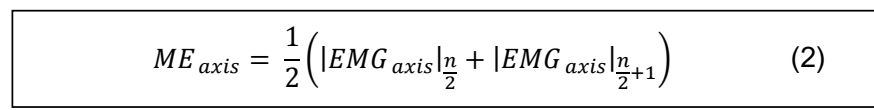

where ME is the median of the energy (median absolute amplitude), is the EMG signal (coming from the accelerometer recording axis), and $\mathrm{n}$ is the time window of the data analysis (variable from 3 to $5 \mathrm{~s}$, with a frequency of acquisition at $1 \mathrm{kHz}$ of 3,000 to 5,000 points).

The surface electrodes were positioned with a bipolar configuration and 2.5-cm inter-electrode distance according to the SENIAM (Surface Electromyography for the Non-Invasive Assessment of Muscles) protocol, parallel to the fibers of the analyzed muscles (trapezius, spinal erectors, external oblique, and rectus abdominis, on both sides). The reference electrode was positioned on the C7 spinous process, and the sampling frequency was $1000 \mathrm{~Hz}$ per channel. Skin cleaning with 70\% alcohol and trichotomy using gloves were performed for better adherence; all materials were for individual use and disposable. Data were collected with the volunteer in a sitting position on a clinical table, with the trunk upright and hands relaxed on the thigh, balancing a book over the head during submaximal contraction, with three 15-s measurements and 30-s intervals between evaluations. 
For postural evaluation, the adolescents were positioned behind the symmetrograph, on the base platform (for elevation to the level of the lines drawn on the device), in an orthostatic position with the arms positioned along the body, heels slightly apart, and feet abducted approximately $15^{\circ}$, with the head in the Frankfurt plane. In this analysis, the bases of the Kendall protocol ${ }^{13}$ were held. As a reference, the anatomical structures observed in the evaluation of the postural ideal were in the anterior view, beginning from the centerline of the symmetrograph between the middle distance of the heels; ascending and passing through the lower limbs, dividing them into equal parts; the mid and central lines of the pelvis; Alba line; sternum; and skull. The structures in the lateral view were those from the anterior to the lateral malleolus, joint center of the hip, the shoulder, and the external auditory meatus. Finally, the structures in the posterior view were those between the average distance of the heels; rising and passing through the lower limbs, dividing them into equal parts; the middle and central line of the pelvis; the spinous processes of the spine, from the lumbar region to the thoracic region; and then culminating in the cervical region and skull.

The adolescents assessed underwent 24 sessions of a treatment protocol consisting of $14 \mathrm{PM}$ floor exercises as follows, with classes twice a week with a duration of 45 min: hundred, roll-up, front support push-up, leg pull-down, neck pull, teaser, scissors, rollover, swimming, single-leg stretch, double-leg stretch, crisscross, shoulder bridge, and spine twist ${ }^{14}$. Statistical analyses were performed with

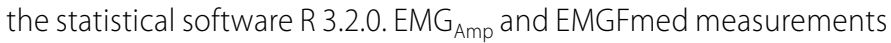
were compared with an analysis of variance (ANOVA). ANOVA ${ }^{15}$ is used to evaluate the influence of factors on the characteristic of interest. In the present study, the factors associated with $E M_{A m p}$ and $E M G_{\text {Fmed }}$ values were as follows: Period, before or after the PM; Muscle, musculature (trapezius, erector spinae, oblique, and rectus abdominis), and Side, side of the body (right or left). In the ANOVA, statistical methods are applied that partition the total variability of the data between the factors analyzed and the residuals, and then an $\mathrm{F}$ test is applied to verify if the variation explained by the factors is significant compared with the variation of the residuals. The model that was tested can be written using equation (3),

$$
y_{i j k l}=\mu+\alpha_{i}+\beta_{j}+\gamma_{k}+\epsilon_{i j k l}
$$

where $\mathrm{I}=1, \ldots, \mathrm{n}, \mathrm{i}=1.2, \mathrm{j}=1, \ldots, 4, \mathrm{k}=1,2$, and $=1$ - ith observation of level $i$ of Period, level $j$ of Muscle, and level $k$ of Side; $\mu$ $=$ general mean of data; $a_{i}=$ effect of level $\mathrm{i}$ of Period; $\beta_{j}=$ effect of level $\mathrm{j}$ of Muscle; $\gamma_{\mathrm{k}}=$ effect of level $\mathrm{k}$ of Side; and ${ }_{\mathrm{ijkl}}=$ random component of the error.

To enable such an analysis, we assumed that the experimental errors were independent random variables and identically distributed with a normal distribution with a zero mean and constant variance, that is, . The verification of these assumptions was performed graphically, seeking an absence of patterns in the Residuals versus Fitted graph. Possible outliers with more than three residuals in the Normal Q-Q graph were removed from the analysis. The adherence of the points to the line of the theoretical normal distribution was also observed in the Normal Q-Q graphs. In cases where the adequacy of the residuals was not achieved, a log transformation was applied to the measures observed; in all cases where transformation was needed, this measure was sufficient to validate the assumptions. It is important to emphasize that with the use of the transformation, we cannot refer to the measures of $E M G_{A m p}$ or $E M G_{\text {Fmed }}$ in their original scale but instead apply the Napierian logarithm to these measures. Given the small sample size, the level of statistical significance adopted was $10 \%$.
The hypotheses tested with ANOVA were

\begin{tabular}{c|}
$\frac{\left\{\begin{array}{l}H_{0}: \alpha_{1}=\alpha_{2} \\
H_{1}: \alpha_{1} \neq \alpha_{2}\end{array}\right.}{\square}$ \\
$\left\{\begin{array}{c}H_{0}: \beta_{1}=\beta_{2}=\beta_{3}=\beta_{4} \\
H_{1}: \beta_{j} \neq \beta_{j^{\prime}} \text { for at least one pair with } i \neq i^{\prime}\end{array}\right.$ \\
$\qquad\left\{\begin{array}{l}H_{0}: \gamma_{1}=\gamma_{2} \\
H_{1}: \gamma_{1} \neq \gamma_{2}\end{array}\right.$ \\
\hline
\end{tabular}

The McNemar's test was used for the symmetrographic analysis. This nonparametric test was applied in comparative situations before and after, evaluating the same individual in these two periods to verify the statistical significance of the class changes that occurred. Asymmetrical Thales triangle, scapular protraction, trapezius shortening, asymmetric shoulders, abdominal protrusion, and hip asymmetry were verified, as well as the presence or absence of scoliosis. The $\mathrm{p}$-value was obtained through a binomial test, as the sample size of the class changes was small, and , in which $p_{0}=0.5, x=0$ for all cases, and $\mathrm{n}$ is the number of individuals that presented evolution (difference between Yes before and Yes after).

\section{RESULTS}

In the RCTS, the measure of EMG $\mathrm{Amp}_{\text {p }}$ was transformed, and a significant difference was found between before and after $(p \approx 0)$ and between the muscles $(p \approx 0)$, according to Table 1. The measures of EMG $\mathrm{Fmed}_{\text {fmod }}$ showed a difference only between before and after $(p \approx 0)$, according to Table 2 . The analyses of residuals (Figure 1) show the adequacy of the models and the validity of the analyses, even with a slight deviation from normality of the residuals of the $f$ measures. Figure 2 shows the mean $E M G_{A m p}$ (left) and $E M G_{\text {Fmed }}$ (right) per period and musculature.

The most prominent muscles for $\mathrm{EMG}_{\text {Amp }}$ were the TRAP and ERE. An increase in mean $E M G_{A m p}$ was found for ERE in cases of RCTS. In turn, the behavior of the muscles for measures of $E M_{\text {Fmed }}$ revealed a higher mean increase for the RA and OBLI muscles.

\section{DISCUSSION}

In the classification of RCTS, the decrease in $\mathrm{EMG}_{\text {Amp }}$ in the TRAP, OBLI, and RA muscles, and the increases in $E M G_{\text {Fmed }}$ on both sides of the spine promoted neuromuscular adjustments and thus showed improvement in the postural evaluation measured with SMTG in one of the adolescents assessed.

These findings are in agreement with a study ${ }^{16}$ that reported that the first few weeks are considered responsible for the neural adaptations to the exercises and that only after the eighth to the tenth week do the physiological adaptations of strength and resistance occur. Thus, some statements ${ }^{16}$ are important because they provide evidence that the short period of application of the therapeutic protocol proposed in the

Table 1. ANOVA EMG ${ }_{\text {amp }}(\mu \mathrm{V})$ - Right Convex Thoracolumbar Scoliosis (RCTS).

\begin{tabular}{c|c|c|c|c|c}
\hline & GL & $\begin{array}{c}\text { Sum of } \\
\text { Squares }\end{array}$ & Mean Squares & F Calculated & $\mathbf{P}(>\mathbf{F})$ \\
\hline Period & 1 & 84.00 & 84.00 & 31.85 & 0.000 \\
\hline Side & 1 & 3.48 & 3.48 & 1.32 & 0.2544 \\
\hline Muscle & 3 & 134.27 & 44.76 & 16.97 & 0.0000 \\
\hline Residuals & 74 & 195.18 & 2.64 & & \\
\hline
\end{tabular}

Table 2. ANOVA EMG fmed $_{(}(\mu \mathrm{V})$ - Right Convex Thoracolumbar Scoliosis (RCTS).

\begin{tabular}{c|c|c|c|c|c}
\hline & GL & Sum of Squares & Mean Squares & F Calculated & P (>F) \\
\hline Period & 1 & 62105.51 & 62105.51 & 46.41 & 0.000 \\
\hline Side & 1 & 2.11 & 2.11 & 0.00 & 0.9684 \\
\hline Muscle & 3 & 5486.44 & 1828.81 & 1.37 & 0.2596 \\
\hline Residuals & 74 & 99017.42 & 1338.07 & & \\
\hline
\end{tabular}




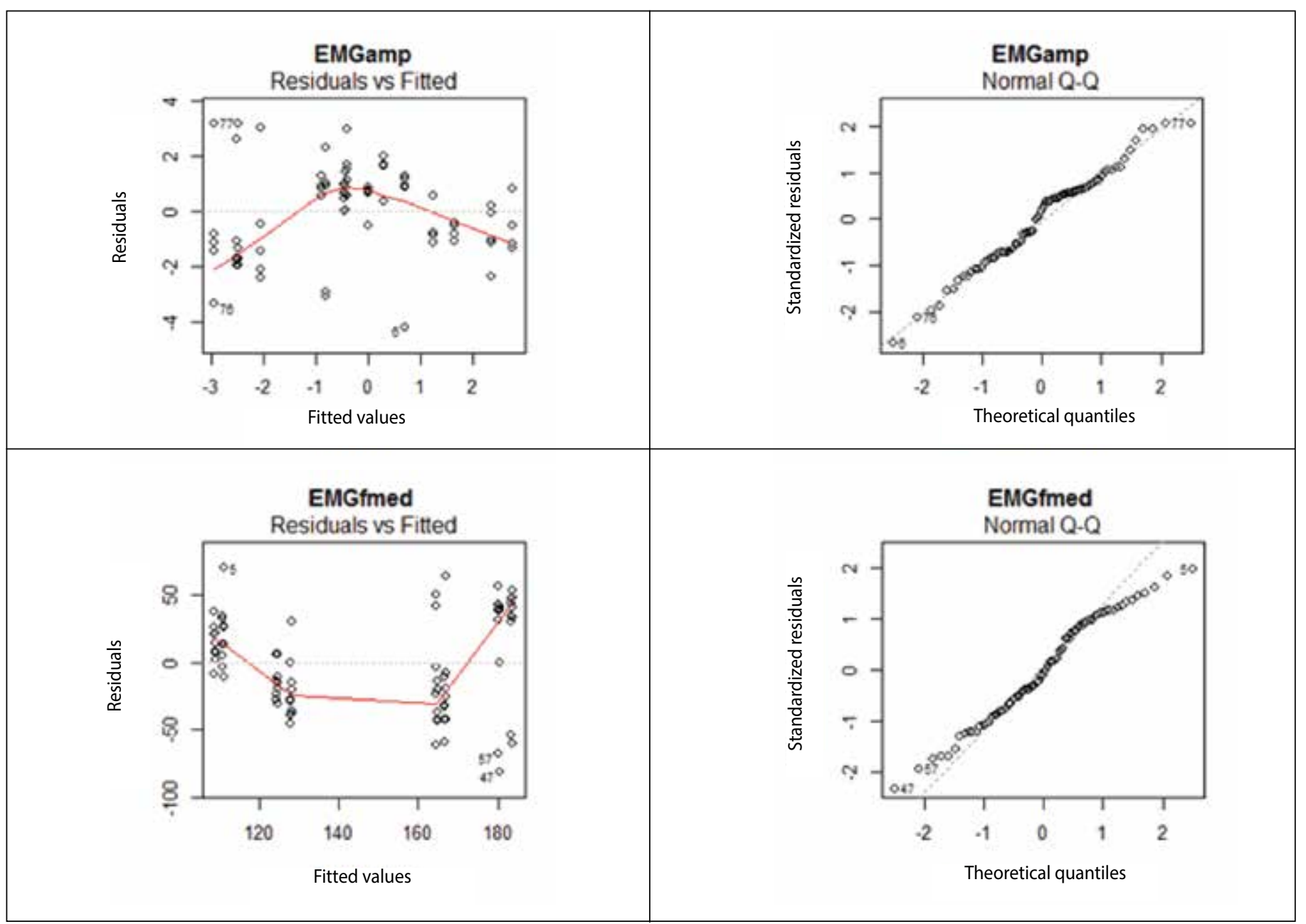

Figure 1. Analysis of residuals ( $E M G_{\text {amp }}$ and $\left.E \mathrm{MG}_{\text {fmed }}\right)$ in cases of right convex thoracolumbar scoliosis

present study was insufficient to promote satisfactory muscle strength changes to generate small modifications in the asymmetries presented in all five adolescents with the classification of RCTS, where only one of the adolescents assessed displayed improvement in scoliosis and asymmetric shoulders. However, they provided relevant neuromuscular activation.

The electromyographic examination revealed a significant effect on the neuromuscular activation pattern due to the restoration of the strength of the muscle through neuromuscular facilitation and increasing the velocity of propagation of action potentials of motor units ${ }^{17}$ that promote an increase in muscular action ${ }^{18}$ and improves intermuscular and intramuscular coordination of agonists and antagonists 19,20 . The assessment of postural control represents a challenging task but has important implications to professionals from diverse areas such as neurology, physiotherapy, and orthopedics ${ }^{21}$. Moreover, as scoliosis is a potentially progressive disease, surface EMG examination is important in controlling the evolution of this deformity and in treatment decisions.

The PM provides a strengthening of the basic muscle components, producing proprioceptive stimuli that result in improvement of the static equilibrium of the spine ${ }^{22}$. Accordingly, these assertions are fundamental in the validation of the conservative treatment with the PM in spinal diseases. However, in the pathology of RCTS scoliosis, the variable Cobb angle of $>40^{\circ}$ is suggested to be a limiting factor in the benefits relating to therapeutic action, promoting only stabilization in the progression of the disease.

The postural responses may also be related to the constant interruption in movement resulting from pain, in which the volunteer with surgical indication had to cease the execution of movements on several occasions, not completing the number of repetitions necessary in each exercise elected to structure the conservative PM treatment protocol.
In this context, one must mention a case study ${ }^{23}$ held in the city of Bauru, São Paulo, of an 11-year-old girl with a $16^{\circ}$ RCTS scoliosis confirmed radiographically who underwent a 9-month treatment protocol consisting of kinesiotherapeutic exercises together with the techniques of iso-stretching, Pilates, Williams series, and exercises using the Swiss ball. The Cobb angle was reduced by $4^{\circ}$, and clear postural improvement was observed. These results support in part the results presented herein in which the importance of treatment protocols applied during longer therapeutic intervention periods relative to the postural benefits can be observed.

Likewise, a 19 year-old patient was evaluated ${ }^{24}$, and a decrease in muscle retractions was observed after using the iso-stretching method and Swiss ball, and the patient presented an improvement in postural pattern and pain sensation, but without reducing the scoliotic curvature. These results corroborate also in part those presented in this study, which verified that the treatment protocol with $24 \mathrm{PM}$ sessions was also not effective in reducing all muscular asymmetries evaluated in the frontal and sagittal plane using SMTG, presenting only improvement in one adolescent in terms of scoliotic curve reduction.

Another case study ${ }^{25}$ of a 14-year-old male adolescent with RCTS corroborated the usefulness of physiotherapeutic treatments in scoliosis disease. The treatment consisted of isometric, symmetrical, and asymmetric kinesiotherapeutic exercises on the concave and convex sides, and stretching favoring axial growth performed in the sitting and lying positions. After 22 months of treatment with two to three sessions a week and 1-hour interventions, the results showed a reduction of scoliotic curvature on radiographic examinations.

This remarkable reduction of the scoliotic curvature confirms the need for treatments performed through exercises during an extended period of therapeutic intervention as a factor of postural benefits. Isometric exercises 


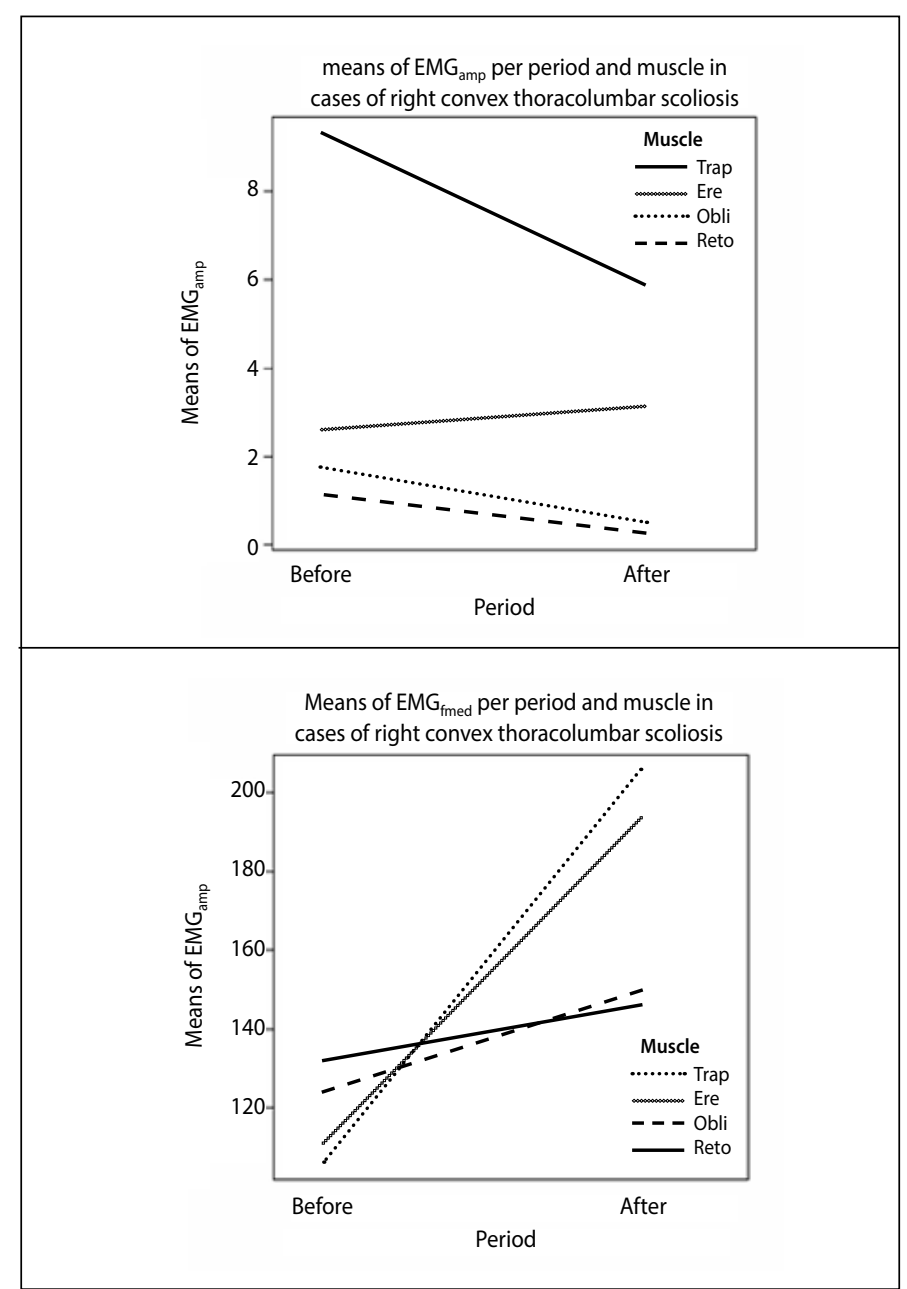

Figure 2. Means of $E M G_{\text {amp }}$ (left) and $\mathrm{EMG}_{\text {fmed }}$ (right) per period and musculature in cases of right convex thoracolumbar scoliosis for the dorsal, lumbar, and abdominal muscles, similar to those recommended in the PM, can be important in the composition of treatment protocols in the stabilization of the spine in adolescents with scoliosis, confirming the results found in the present study. Furthermore, postural evaluation using SMTG was efficient for verifying changes in body structure.

These data should be interpreted with caution, as they are based on a small sample of RCTS cases and require further analysis with larger samples of this specific classification of the disease and with protocols composed of different PM exercises.

\section{CONCLUSION}

The time of application of the PM therapeutic intervention protocol was not effective in reducing all bodily asymmetries assessed, as only one of the five adolescents studied showed improvement in scoliosis and asymmetrical shoulders (representing 20\%). In addition, in three individuals with hip asymmetry, only one volunteer (33.33\%) showed an improvement, as demonstrated on SMTG.

In the RCTS, measures of EMG $\mathrm{Amp}_{\text {p }}$ demonstrated a significant difference between before and after the protocol $(p \approx 0)$ and among the muscles $(p \approx 0)$. The measures of $E M G_{\text {Fmed }}$ demonstrated a significant difference only between before and after the protocol $(p \approx 0)$.

The most prominent muscles for $E M G_{\text {Amp }}$ were the TRAP and ERE, and the mean $\mathrm{EMG}_{\text {Amp }}$ for ERE was increased in the RCTS cases. Regarding the measurements of $E M G_{F m e d}$, the mean increase was higher for the RA and OBLI muscles.

Thus, EMG can be an important examination in the study and monitoring of neuromuscular activity concerning the evolution of scoliosis, and SMTG is an efficient technology with low cost and accessible application in postural evaluation.

All authors declare no potential conflict of interest related to this article

AUTHORS' CONTRIBUTIONS: Each author made significant individual contributions to this manuscript. WADS (0000-0003-1845-066X)*, contributed to the data collection activities and writing of the manuscript; AMWS (0000-0003-3388-3017)*, provided guidance for the study outline and review; LMB (0000-0001-7812-1011)*, assisted in the statistical analysis and review; KRGO (0000-0002-6921-853X)*, assisted in the statistical analysis. *ORCID (Open Researcher and Contributor ID).

\section{REFERENCES}

1. Karimian A, Rahmani N, Mohseni-Bandpei MA, Bassampour SA, Kiani A. Prevalence of Scoliosis and Associated Risk Factors in Children and Adolescents: A Systematic Review. Journal of Mazandaran University of Medical Sciences (JMUMS). J Mazandaran univ Med Sci. 2015;25(130):191-9.

2. Souza FID, Ferreira RBD, Labres D, Elias R, Sousa APMD, Pereira RE. Epidemiologia da escoliose idiopática do adolescente em alunos da rede pública de Goiânia-GO. Acta Ortop Bras. 2013;21(4):223-5.

3. De Oliveira JG, De Oliveira MMHA, Alfieri FM. Lombalgia e Estilo de Vida. J Health Sci. 2015;16(4):341-4.

4. Macedo RB, Coelho MJ, Sousa NF, Valente-dos-Santos J, Machado-Rodrigues AM, Cumming SP, et al. Quality of life, school backpack weight, and nonspecific low back pain in children and adolescents. J Pediatr (Rio J). 2015;91(3):263-9.

5. Gonçalves M, Barbosa FSS. Análise de parâmetros de força e resistência dos músculos eretores da espinha lombar durante a realização de exercício isométrico em diferentes níveis de esforço. Rev Bras Med Esporte. 2005;11(2): 109-14.

6. Fusco C, Donzelli S, Lusini M, Salvatore $M$, Zaina F, Negrini, $S$. Low rate of surgery in juvenile idiopathic scoliosis treated with a complete and tailored conservative approach: end-growth results from a retrospective cohort. Scoliosis. 2014;9:12.

7. Mordecai SC, Dabke HV. Efficacy of exercise therapy for the treatment of adolescent idiopathic scoliosis: a review of the literature. Eur Spine J. 2012;21(3):382-9.

8. Zaina F, Romano M, Knott P, de Mauroy JC, Grivas TB, Kotwicki T, et al. Research quality in scoliosis conservative treatment: state of the art. Scoliosis. 2015;10(21):1-4

9. Mac-Thiong JM, Roussouly P, Berthonnaud É, Guigui P. Sagittal parameters of global spinal balance: normative values from a prospective cohort of seven hundred nine Caucasian asymptomatic adults. Spine (Phila Pa 1976). 2010;35(22):E1193-8

10. Negrini A, Negrini MG, Donzelli S, Romano M, Zaina F, Negrini S. Scoliosis-Specific exercises can reduce the progression of severe curves in adult idiopathic scoliosis: a long-term cohort study. Scoliosis. 2015;10:20.

11. Jago R, Jonker ML, Missaghian M, Baranowski T. Effect of 4 weeks of Pilates on the body composition of young girls. Prev Med. 2006;42(3):177-80.

12. Bertolla F, Baroni BM, Leal Junior EC, Oltramari JD. Efeito de um programa de treinamento utilizando o Método Pilates ${ }^{\oplus}$ na flexibilidade de atletas juvenis de futsal. Rev Bras Med Esporte. 2007;13(4):222-6. 13. Kendall FP, McCreary EK, Provance PG, Abeloff D, Andrews PJ, Krausse CC. Músculos, provas e funções: com postura e dor. 5ed. São Paulo: Manole; 2007.

14. Rodriguez J. Pilates. 1st ed. São Paulo: Marco Zero; 2006.

15. Bussab WO, Morettin PA. Estatística básica. 8ed. São Paulo: Saraiva; 2013.

16. Menacho MO, Obara K, Conceição JS, Chitolina ML, Krantz DR, da Silva RA, et al. Electromyographic effect of mat Pilates exercise on the back muscle activity of healthy adult females. Journal manipulative and physiological therapeutics. J Manipulative Physiol Ther. 2010;33(9):672-8.

17. Noda DKG, Marchetti PH, Junior GDBV. A Eletromiografia de superfície em estudos relativos à produção de força. Rev CPAQV. 2014;6(3):1-25.

18. Bohorquez IJR, Souza MN, Pino AV. Influência de parâmetros da estimulação elétrica funcional na contração concêntrica do quadríceps. Rev Bras Eng Bioméd. 2013;29(2):153-65.

19. Folland JP, Williams AG. The Adaptations to Strength Training: Morphological and Neurological Contributions to Increased Strength. Sports Med. 2007;37(2):145-68.

20. Paz GA, Lima VP, Miranda H, de Oliveira CG, Dantas EHM. Actividad electromiográfica de los músculos extensores del tronco durante la estabilización física del método Pilates. Rev Andal Med Deporte. 2014;7(2):72-7.

21. Loth EA, Albuquerque CE, Ciena AP, Rossi AG. Avaliação do controle postural em adultos jovens através da posturografia dinâmica Foam-laser e plataforma de força. Rev Bras Med Esporte. 2011;17(3):171-4.

22. Santos FDRP, Moser ADDL, Bernardelli RS. Análise da efetividade do método Pilates na dor lombar: revisão sistemática. Rev Bras Ciênc Mov. 2015;23(1):157-63.

23. Fiorelli A, Arca EA, Fiorelli CM, Vitta AD, Weckwerth PH, Strandman MTM, et al. Redução da escoliose idiopática juvenil pós-intervenção cinesioterapêutica: relato de caso. Rev Salusvita. 2014;33(3):355-63.

24. Bonorino KC, Borin GS, Da Silva AH. Tratamento para escoliose através do método iso-stretching e uso de bola suiça. Cinergis. 2007;8(2):1-5.

25. De Oliveira CM, Teixeira GMR, Cubo RCP. Tratamento fisioterapêutico por meio da cinesioterapia na escoliose idiopática do adolescente: relato de caso. Rev funec científica-multidisciplinar. 2014;3(5):122-30. 